\title{
An Overview of the Impact of Special Anti-Robbery Squad (SARS) in Nigeria
}

\author{
Ogbette, Afamefuna Samuel (corresponding author) \\ Department of Public Administration and Local Government \\ University of Nigeria, Nsukka \\ E-mail: ogbetteafamefuna@ymail.com \\ Idam, Macben Otu \\ University of Nigeria, Nsukka \\ Department of Public Administration and Local Government \\ E-mail: macben.idam@unn.edu.ng \\ Kareem, Akeem Olumide \\ Department of Public Administration and Local Government \\ University of Nigeria, Nsukka \\ E-mail: olumideak14@gmail.com
}

Received: Oct. 8, 2018 Accepted: Oct. 29, 2018 Online published: Oct. 31, 2018

doi:10.5296/ijhrs.v8i4.13846 URL: https://doi.org/10.5296/ijhrs.v8i4.13846

\begin{abstract}
This study examined the impact of Special Anti-Robbery Squad (SARS) in Nigeria. It solely depended on the secondary source for information. SARS is one of the Nigeria Police Force units that is saddled with the responsibility of fighting crime in the society; specifically, robbery and kidnapping. The impact was examined in two ways: Positive and Negative impact. From the positive point of view, SARS has been able to reduce robbery and kidnapping to an extent but unfortunately, people now use them as bodyguards to intimidate, suppress, and harass other people. From our findings, SARS tortures people mercilessly, extort, beat, kill and jail people who are not forthcoming with their demands. It was also discovered that, most of them lacks orientation on human relation which is a big gap the
\end{abstract}


Nigeria Police Force need to cover by re-orienting them. Again, it was discovered that some of the personnel smoke and drink. They are often intoxicated while on duty, wielding sophisticated guns. From the study, the following recommendations were made: control measures should be put in place for SARS to be stopped from torturing people. They should equally be stopped from extorting, beating, killing (except in a battle ground) and framing people up just to be jailed. Investigative jobs as that of SARS should be exclusively for graduates in the Police Service. Again, the Nigeria Police Force and Nigeria Police Service Commission need to often re-orient these officers on human relations. Finally, officers caught drinking or smoking (especially hard drugs) on duty should be properly dealt with to serve as a deterrent to others.

Keywords: SARS, impact, Nigeria

\section{Introduction}

Special Anti-Robbery Squad, SARS, is a dreaded anti-crime unit of the Nigeria Police Force founded in 1992 by Simeon Danladi Midenda, a retired Commissioner of Police who added the word ' 'Special', to the already existing Anti-Robbery Squad which turned out to be Special Anti-Robbery Squad (SARS). That was how the name SARS came into the Nigeria Police vocabulary (Nnadozie, 2017). He further stated that Simeon Danladi Midenda was the Nigerian Contingent Commander to United Nations Mission in Bosnia and Herzegovina in 1998.

According to Spokesman of the Police Force, Jimoh Moshood, SARS is one of the 14 units under the Nigeria Police Criminal Investigation and Intelligence Department which was created to arrest, investigate and prosecute people involved in violent crimes such as armed robberies, murders, kidnappings, hired assassinations and other forms of extreme criminality (Okogba, 2017). Anti-Robbery as a modus operandi of the Nigeria Police Force for combating armed robbery has been as old as the Police Force itself. As a unit also, anti-robbery had always existed in all Criminal Investigation Departments at Force Headquarters, Zonal and State Command levels.

According to Simeon Danladi Midenda, one major incident that prompted the creation of SARS was when Col. Rindam, a military officer from Plateau State met his death at the hands of police operatives at a check point in Lagos. Upon discovery of that, the army took to the streets in Lagos in search of policemen. As a result, policemen abandoned the streets in Lagos and withdrew to barracks. Robbers then had a field day in Lagos, operating with impunity. It took two weeks of talks before the military and police authorities succeeded in convincing the army chaps to return to barracks and for the police to come back to the roads. By that time, it was too late. Armed robbers were in control in Lagos and the like of Shina Rambo could not be challenged by any force (Nnadozie, 2017).

There is no doubt, policing is a complex job all over the world. This is because every action the police personnel take at any point in time attracts different interpretations by different people. Police are also part of organizations in the world that have more enemies than friends. In fact, a friend to the police today may tomorrow become the enemy because of vested 
interest. The recent campaign in the social media calling for the scrapping of the Special Anti-Robbery Squad (SARS), a unit of the Nigeria Police Force, has attracted mixed feelings. This is because, while many others have had sour encounter with personnel of the unit, others or their relations have, at one time or the other, been rescued from either kidnappers or deadly armed robbers by the officers of the SARS unit. SARS is a special unit of the Nigeria Police Force which was specially created to combat violent crimes (Muhammad, 2017).

But unfortunately, people with the financial muscle have been reported to have used SARS to suppress, intimidate, harass, frame and jail people. To an extent, good numbers of SARS personnel are corrupt and psychologically imbalance, most especially the way the handle gun and releases bullet anyhow without no just cause. The researchers have seen SARS officers on different occasions smoking and drinking on duty which most times result to releasing bullets mistakenly to innocent people in the name of Accidental Discharge. Then, we begin to ask: does it mean that Nigeria Police Force does not have rules guiding SARS unit on when and how to handle gun? Thus, this paper is to examine the impact of SARS in Nigeria.

\section{Impact of SARS in Nigeria}

The impact of SARS can be categorized into two fundamental parts- Positive impact and Negative impact. Under the positive impact, SARS, according to many, has over the years, performed excellently well as it has assisted in arresting some notorious criminals in different parts of the country. In the account of Muhammad, (2017), it is instructive to note that the same SARS many people are calling for it to be scrapped was instrumental to the arrest of most of the notorious criminals in many parts of the country. He gave an instance of, sometimes last year, two suspected notorious armed robbers terrorizing and robbing residents of Ire Akari street, Ejigbo and Isolo areas of Lagos, snatching and vandalizing vehicles in the area for long, were arrested by operatives of the Federal Special Anti-Robbery Squad (FSARS) in Adeniji Adele Road, Lagos Island. This, no doubt, brought a sigh of relief to residence of the area.

Similarly, in 2015, due to the unabated activities of cultists and other violent crimes, including kidnapers and armed robbers in Edo State, the Inspector General of Police (IGP) Idris, dispatched a special crack squad comprising SARS officers to the state to tackle the situation. The situation was, few days after, brought under control. As record may have it, SARS has been able to arrest more than three thousand suspected kidnappers across the country and in fact, the recent successes recorded in reducing the high rate of crime and criminality, especially kidnapping and other deadly vices in most parts of the country, is largely the handiwork of SARS operatives (Muhammad, 2017).

Another major success was the arrest of the notorious kidnappers that terrorized the country for more than six years, popularly known as Henry Chibueze a.k.a Vampire and Onwumadike Chukwudumeme a.k.a Evans, was achieved following the ingenuity and gallantry displayed by the SARS unit of the Force (Muhammad, 2017).

Few months ago, the Abuja-Kaduna Highway became a danger zone as kidnappers and armed robbers almost took over the road. Many prominent Nigerians had been kidnapped and 
robbed on that axis. The story has become different today because of the immense contribution of SARS operatives who were drafted to that highway. Again, it is relevant to know that not all the alleged wrong doings attributed to the SARS personnel are actually committed by them. Many bad elements have been arrested in recent times for impersonating or claiming to be SARS personnel (Muhammad, 2017).

On the Negative impact of SARS, just as there is no perfect human institution or person, one cannot deny the fact that SARS also has some bad elements who have acted over time beyond their line of responsibility (Muhammad, 2017). SARS as we have it today has created space for external influence through the power of money. People with the financial muscle now use their money to control SARS (bad elements) by telling them who to arrest, slap, harass and so on, thereby, shifting them away from the original reason (s) why the Unit was created. In Nigeria, you can' t move around freely with a starched shirt, flashy nice wrist-watch, a portable nice phone (like iPhone) and car without being harassed and extorted for dressing fine. Today in Nigeria, living well by changing cloths and cars is a big crime before the SARS personnel. The already have this perception that when you live fine that means you are a yahoo boy (fraudster), forgetting the fact that there are greater number of Nigerians who are really doing well in their different businesses. If you are lucky when caught up by them (SARS), you shall be asked to pay reasonable amount of money to their account but if you are not, you may be shot, jailed, robbed or framed up.

Fighting fraudsters in Nigeria and indeed in the world is a very important thing to do but is never the duty of SARS. Other agencies like Economic and Financial Crime Commission (EFCC), Independent Corrupt Practices Commission and other related offences (ICPC) could take up that function if supported by law. These fraudsters stay mostly in states with $4 \mathrm{G}$ networks like Lagos, Delta, Edo, Imo and so on. But, before fighting them, there must be glaring opportunities and alternative sources of livelihood in Nigeria if not, the problem will continue to be there.

In September 2016, Amnesty International (AI) followed in the trail of widespread complaints by citizens and published a report accusing the Squad of subjecting its detainees to horrific torture in form of hangings, beatings, humiliation, shootings, mock executions and extortions (Vanguard, December 6, 2017). In our humble submission, all these have really given SARS a bad name in Nigeria.

\section{Nigerians and Their Personal Experiences with SARS}

Nigerians recount their ordeals with men of the Special Anti-Robbery Squad (SARS), as the campaign for the dismantling of the security unit continues. The mainly online campaign with the hashtag \#EndSARS followed widespread allegations of corruption and inhuman treatment of citizens by the special police squad. The victims said their experience with the police unit has been bad and called for termination of their activities (Group, 2018). Mr. Elijah Balogun relates his experience in a tweet. " SARS stopped the Uber cab my friend and I were riding in April this year (2018). They told us to come down. Started asking for our phones and threatened to take my friend away because he has beard and looks like a G boy (fraudster). Lastly, they begged us to drop 'something' . \#EndSARS' ' he tweeted (Group, 2018). 
While relating his experience, a blogger who identified himself as Ladi, said he was threatened while attending a conference. ' ' this fateful day just last week or thereabouts, I was to attend the Lagos Digital Summit. I took a taxify from the office to the venue and met them around Sheraton Link Road. They stopped the cab and asked me to come down. Asked me to identify myself which I did and asked for my ID card and Complimentary Card which were unavailable. They threatened to arrest me but my saving grace was because my mum was in the police before she passed on so as they were threatening me to settle them if I don' $t$ have a ID, I was also threatening them with dismissal via a secret camera which was live and on me. After about 3hours, I was allowed to go but not without calling my Uncle who is a commodore in the Nigerian Navy' ' ... he tweeted (Group, 2018).

Another victim, a student of the University of Ibadan, who identified himself as Sunday, said he was beaten by SARS officers for a crime he knew nothing about. ' 'Early in the morning while I was still sleeping, SARS officers broke into my house, I was beaten, molested and arrested because someone in my neighborhood allegedly committed a crime. I spent twelve days in their custody and released after paying a huge sum...he tweeted (Group, 2018).

Nkyjoye, an alumnus of the University of Benin, also narrated his encounter with SARS officers. ' ' I had same experience in 2011 when I was in UNIBEN. I went out with my friends. About 10pm on our way home, they stopped our car, asked my friend who was driving to unlock his phone and he refused. So they took us to the station and laid allegations that we were kidnappers. We slept in their station and the next day was an environmental. It was crazy' ' he tweeted (Group, 2018).

Minitracy @T_Oluwani tweeted that SARS almost beat a guy in my street recently, it were women in my street that intervened, and when we asked what he did, they said he is too fresh to be a shoemaker and also he is wearing only singlet, in front of his workshop ooo...just imagine? Na that day i no say dem no get sense (Mansur, 2018).

Again, Abdul Abdukareem encountered officers of Nigeria' s Special Anti-Robbery Squad (SARS) a month ago in Lagos. He and two friends were on their way home around Idi-Araba, Surulere when officers turned up in a minibus and arrested them. It was around 10pm, I stopped at a store opposite my house with two friends to pick up bread for breakfast the next morning, he said. The officers appeared out from nowhere and drag us into their van without telling us what our offence was. The officers took them, along with twelve others, to Area D police station in Mushin and threw them into a cell. On our way to the police station, the officers kept picking up random people and throwing them into the van. Anyone that asked questions got slapped according to Abdul. We all slept in the station which was a bad experience then in Abdul and his friends were released with the of N20,000. They laughed at us and said it was normal (Development, 2018).

\section{Overhaul of SARS in Nigeria}

On August 14, 2018, the Acting President, Professor Yemi Osinbajo ordered the Inspector General of Police (IGP) Ibrahim Idris, to restructure the Special Anti-Robbery Squad (SARS) unit. He gave the order after receiving several complaints. Below is the major reason why 
he ordered that the unit should be overhauled. The persistent complaints and reports on the activities of SARS that border on allegations of human rights.

Hence forth, their new activities would be:

- To conduct their operations in strict adherence to the rule of law and with due regard to international humanitarian law.

- To ensure that their activities will be intelligence-driven.

- The unit will also be restricted to the prevention and detection of armed robbery and kidnapping, and apprehension of offenders linked to the stated offences (Eseohe, 2018).

\subsection{New Measures Taken by the Nigeria Police Force}

- The Inspector General of Police, Ibrahim Idris, has ordered members of the Special Anti-Robbery Squad (SARS) to wear police uniforms with full identification, pending the launch of new FSARS uniform.

- The overhaul of FSARS operatives had been ordered to desist from attending to civil or commercial matters henceforth and focus strictly on armed robbery and kidnapping cases only.

- Human rights desk had been created in the 36 states of the federation and FCT under the supervision of Habiru Gwandu (Commissioner of Police in charge of FSARS) and the desks would address cases of infractions against members of the public by FSARS personnel across the nation.

- The Police will henceforth engage the services of psychologists and counselors in the ongoing screening of FSARS operatives (Agency Report, August 25, 2018).

On September 5 being Wednesday, 2018, the IGP Idris restates ban on SARS operatives from conducting stop and search raids. The Inspector-General of Police Ibrahim Idris, repeated his warning to Special Anti-Robbery Squad (SARS) to stop indiscriminate search of citizens. $\mathrm{Mr}$ Idris reportedly issued the latest directive at a training organized for SARS operatives in Anambra State.

- You are barred from searching handsets and laptops of innocent citizens, unless the search is directly linked to a case or directed by IGP or any person or persons he so delegated. This was through Amaechi Elumelu, the national coordinator of x-Squad.

- Officers are to stop keeping suspects in perpetual custody without filing court charges, saying they now have a maximum of two days to take issues to court.

- Henceforth, any FSARS officer who detains any suspect beyond 48 hours without recourse to the court risks dismissal.

\section{Methodology}

This study which centered on overview of impact of SARS (Special Anti-Robbery Squad) in 
Nigeria relied on secondary source of information. The research design used in this work was documentary. Secondary sources of data collection are Internet materials, and Newspapers relevant to this study.

\section{Results}

1. From our findings, SARS torture people mercilessly, extort, beat, kill and jail people who are not forthcoming with their demands.

2. It was discovered that, most of them lacks orientation on human relation which is a big gap the Police Force need to cover by re-orienting them.

3. Again, it was discovered that some the personnel smoke and drink on duty which in most cases intoxicates them and you know what that means when they have guns with them.

\section{Recommendations}

From the study, the following recommendations were made; SARS should be stopped from torturing people and investigative jobs like that of SARS should be left for educated in the Police Service to do so and they should equally be stopped from extorting, humiliating, beating, killing (except in a battle ground) and framing people up just to be jailed. Again, the Nigeria Police Force and Nigeria Police Service Commission need to re-orient these officers on human relations on monthly bases, it will help stop people from getting killed by them on daily bases for no just cause. Finally, officers caught drinking or smoking on duty should be properly dealt with to serve as a deterrent to others.

\section{Conclusion}

In all, the study dealt with the impact of SARS in Nigeria. The study will go a long way to let the Nigeria Police Service Commission and other agencies or organs that matters on the need to reform the way SARS perform their activities. We are of the view that SARS personnel should go back to the original mode of operandi in 1992 when it was created newly to avoid these unsettlement in our society just because of them. SARS is a welcome unit and therefore should not be scrapped but reexamined properly in addressing issues raised by Nigerians.

\section{References}

Agency Report (2018, August 25). Police announce six new steps to reform SARS. Premium Times (Online), Retrieved from https://www.premiumtimesng.com/news/ headlines/ 281316-police-announce-six-new-steps-to-reform-sars.html

Development (2018, 19 June). \#ENDSARS: The story behind the Nigeria protests. Stears Business, Retrieved from https://www.stearsng.com/article/endsars-the-stories-behind-the-nigeria-protests

Eseohe, E. (2018, August 14). \#EndSARS: Why Osinbajo ordered the overhaul of SARS. Daily Trust paper, Retrieved from https://www.dailytrust.com.ng/endsars-why-osinbajo-ordered-the-overhaul-of-sars-265753.ht 
$\mathrm{ml}$

Group (2018, December 5). Our ordeal with SARS. The Nation Nigeria, Retrieved from https:thenationonlineeng.net/ordeal-sars-nigerians/

Mansur, I. (2017, December 3). TRENDING: Nigerians say ' enough is enough' , it is time to \#EndSARS. The Cable. Retrieved from https://www.google.com.ng/amp/s/ www.thecable.ng/nigerians-say-end-sars-police-brutality/amp

Muhammad, B.B. (2017, December 07). SARS: The Untold Story. Leadershipngr (Online), Retrieved from http://leadership.ng/2017/12/07/sars-untold-story/

Nnadozie, E. (2017, December 23). How I founded SARS in the Police- RTD CP Midenda. Vanguard News (Online), from http://www.google.com.ng/amp/s/www.Vanguardngr.com/2017/12/founded-sars-police-rtd-cp -midenda/amp/

Okogba, E. (2017, December 06). Nigeria still needs SARS. Vanguard News (Online), Retrieved from http://www.google.com.ng/amp/s/www.vanguardngr.com/2017/12/nigeria-still-needs-sars/am $\mathrm{p} /$

\section{Copyright Disclaimer}

Copyright for this article is retained by the author(s), with first publication rights granted to the journal.

This is an open-access article distributed under the terms and conditions of the Creative Commons Attribution license (http://creativecommons.org/licenses/by/4.0/). 